\title{
Analisis Proses Berpikir Kreatif Menurut Wallas dalam Pemecahan Masalah Fluida Dinamis pada Siswa Kelas XI IPA SMA Negeri Model Terpadu Madani Palu (Ditinjau dari Adversity Quotient)
}

\author{
Erdina Eka Putri, I Komang Werdhiana, dan Kamaluddin \\ eekaputri71@gmail.com \\ Program Studi Pendidikan Fisika FKIP Universitas Tadulako \\ Jl. Soekarno-Hatta Km. 9 Kampus Bumi Tadulako Tondo Palu - Sulawesi Tengah
}

\begin{abstract}
Abstrak - Proses berpikir setiap siswa berbeda-beda dalam memecahkan masalah, sehingga respon mereka pun berbeda-beda. Salah satu faktor yang mempengaruhinya yaitu Adversity Quotient (AQ). Penelitian ini bertujuan untuk mendeskripsikan proses berpikir kreatif siswa kelas XI IPA dalam memecahkan masalah pada materi fluida dinamis yang ditinjau berdasarkan AQ. Penelitian ini merupakan jenis penelitian deskriptif dengan pendekatan kualitatif. Subjek penelitian ditentukan melalui purposive sampling dan penelitian dilakukan di kelas XI IPA SMA Negeri Model Terpadu Madani Palu dengan responden berjumlah 6 orang yang dibagi menjadi 3 kategori yaitu quitter, camper dan climber. Instrumen yang digunakan yaitu angket ARP (Adversity Response Profile), tes dan wawancara. Data dianalisis menggunakan analisis deskriptif. Data yang dianalisis yaitu lembar jawaban siswa dan hasil wawancara. Hasil penelitian menunjukkan bahwa siswa kelas XI IPA dengan masingmasing 3 kategori responden dapat menyelesaikan tes sesuai dengan proses berpikir kreatif menurut tahapan Wallas serta menunjukkan bahwa masing-masing kategori AQ berbeda dalam proses mengerjakan tesnya. Subjek AQ rendah (quitter) sedikit menunjukkan karakteristik berpikir kreatif, subjek AQ sedang (camper) menunjukkan beberapa karakteristik berpikir kreatif dan subjek AQ tinggi (climber) banyak menunjukkan karakteristik berpikir kreatif.
\end{abstract}

Kata Kunci : Adversity Quotient, berpikir kreatif, fluida dinamis, tahapan Wallas

\section{PENDAHULUAN}

Siswono [1] mengemukakan berpikir kreatif diartikan sebagai suatu kombinasi dari berpikir logis dan berpikir divergen yang didasarkan pada intuisi tetapi masih dalam kesadaran. Ketika seseorang menerapkan berpikir kreatif dalam suatu praktek pemecahan masalah, pemikiran divergen menghasilkan banyak ide-ide [1]. Hal ini akan berguna dalam menemukan penyelesaiannya [1]. Menurut Wallas ada 4 tahapan proses berpikir kreatif yaitu (1) preparasi; (2) inkubasi; ilmuninasi; dan (4) verifikasi [2].

Permasalahan yang mendasar dalam dunia pendidikan adalah rendahnya kualitas proses berpikir siswa dalam menyelesaikan masalah fisika. Hal ini ditunjukkan oleh rendahnya penalaran dan kemampuan dalam memecahkan masalah [3]. Kemampuan untuk memecahkan masalah menjadi salah satu fokus yang ingin dicapai oleh guru, sebab melalui kemampuan pemecahan masalah para siswa dapat mengaktualisasikan apa yang mereka dapatkan dari pembelajaran untuk kemudian diterapkan dalam kehidupan mereka. Kemampuan seseorang dapat memecahkan masalah fisika dengan baik pada dasarnya merupakan tujuan utama dari proses pendidikan, melalui kemampuan pemecahan masalah, hasil belajar setiap siswa diharapkan menjadi lebih bermakna, serta hasil dari proses pembelajaran tersebut dapat bermanfaat bagi siswa.

Uloli [4] dalam penelitiannya menyatakan bahwa proses berpikir kreatif mahasiswa pada tahap persiapan sudah baik. Hal ini dibuktikan dari penyelesaian soal mekanika. Mahasiswa sudah mampu mencermati masalah, mengingat materi yang pernah dijumpai dan mencocokkan dengan soal, mengumpulkan informasi berdasarkan pengetahuan belajarnya tentang konsep fisika. Menuliskan apa yang diketahui dan ditanyakan dan mampu menuliskan 3 rumus penyelesaian soal. berdasarkan hasil wawancara, apa yang dituliskan dalam tes penyelesaian soal sesuai dengan hasil berpikir mahasiswa.

Wulantina [5] menyatakan dalam penelitiannya, bahwa proses berpikir kreatif siswa berkemampuan tinggi dalam pemecahan masalah, semua indikator berpikir kreatif menurut Wallas termuat lengkap mulai dari tahap persiapan hingga tahap verifikasi. Proses berpikir kreatif siswa berkemampuan sedang dalam pemecahan masalah menurut Wallas, hanya dua indikator yang terpenuhi yaitu tahap 
inkubasi dan tahap verifikasi. Sedangkan proses berpikir kreatif siswa berkemampuan rendah dalam pemecahan masalah menurut Wallas, keempat tahapan belum terpenuhi dengan baik.

Proses berpikir setiap siswa berbeda-beda dalam memecahkan masalah fisika. Respon mereka pun berbeda-beda [6]. Ada yang berusaha semaksimal mungkin untuk menemukan cara penyelesaian dan tidak mengenal kata menyerah, ada yang cepat puas dan merasa cukup dengan usahanya walaupun masih ada peluang, dan ada juga yang cenderung menyerah atau tidak berani menghadapi suatu permasalahan. Oleh karena itu, Stoltz mengenalkan bentuk kecerdasan baru yang disebut Adversity Quotient (AQ) [7].

Menurut Stoltz, Adversity Quotient (AQ) adalah bentuk kecerdasan selain IQ, SQ, dan EQ yang mempunyai tujuan untuk mengatasi kesulitan. AQ dapat digunakan untuk menilai sejauh mana usaha seseorang ketika menghadapi masalah rumit. Dengan kata lain, AQ dapat dikatakan sebagai semangat juang dan dapat digunakan sebagai indikator bagaimana seseorang dapat keluar dari kondisi yang penuh tantangan atau permasalahan [7].

Terdapat 5 kategori AQ (Adversity Quotient) menurut Stoltz yaitu quitter (AQ rendah), peralihan quitter menuju camper, camper (AQ sedang), peralihan camper menuju climber dan climber (AQ tinggi) [8]. Pengelompokkan kategori AQ berdasarkan skor angket ARP (Adversity Response Profile) seperti pada Tabel 1.

TABEL 1 KATEGORI AQ BERDASARKAN SKOR ARP (STOLTZ DALAM [7])

\begin{tabular}{|c|c|c|}
\hline No. & Skor & Kategori Siswa \\
\hline 1. & 59 ke bawah & Quitter (QT) \\
\hline 2. & 60 sampai dengan 94 & $\begin{array}{c}\text { Peralihan quitter } \\
\text { menuju camper } \\
\text { (QT-CP) }\end{array}$ \\
\hline 3. & 95 sampai dengan 134 & Camper (CP) \\
\hline 4. & 135 sampai dengan 165 & $\begin{array}{c}\text { Peralihan camper } \\
\text { menuju climber } \\
\text { (CP-CB) }\end{array}$ \\
\hline 5. & 166 ke atas & Climber (CB) \\
\hline
\end{tabular}

Sejalan dengan uraian di atas, peneliti terdorong untuk melakukan penelitian tentang proses berpikir kreatif siswa menurut Wallas yang ditinjau dari Adversity Quotient (AQ) pada materi fluida dinamis. Hal ini dapat menjadi pemicu pengembangan kreatifitas siswa dalam aktivitas berpikir pada saat menyelesaikan masalah fisika.
Penelitian dilaksanakan di SMA Negeri Model Terpadu Madani Palu kelas XI IPA semester 1 dengan jangka waktu 3 hari. Subjek dalam penelitian ini adalah siswa kelas XI IPA SMA Negeri Model Terpadu Madani Palu tahun ajaran 2017/2018 sebanyak 26 orang. Selanjutnya berdasarkan hasil skor angket ARP (Adversity Response Profile) 6 orang siswa dipilih sebagai responden dengan 3 kategori berbeda yaitu masing-masing 2 orang kategori quitter ( $A Q$ rendah), camper (AQ sedang) dan climber ( $\mathrm{AQ}$ tinggi) akan mengikuti tes pemecahan masalah dalam bentuk essay dan wawancara.

Teknik analisis data hasil penelitian melalui beberapa tahapan. Pertama melakukan analisis terhadap hasil skor angket ARP yang siswa kerjakan dengan menjumlahkan tiap masingmasing skor yang dipilih oleh siswa kemudian mengkategorikan $\mathrm{AQ}$ berdasarkan skor angket ARP dengan rumus:

$\Sigma X_{\text {tot }}=\left(X_{1,1}+X_{1,2}\right)+\left(X_{2,1}+X_{2,2}\right)+\ldots$

dengan,

$\mathrm{X}_{\text {tot }}=$ hasil skor angket ARP

$\mathrm{X}_{1.1}=$ skor nomor 1 , pernyataan pertama

$X_{1.2}=$ skor nomor 1 , pernyataan kedua

$\mathrm{X}_{2.1}$ = skor nomor 2, pernyataan pertama

$\mathrm{X}_{2.2}=$ skor nomor 2, pernyataan kedua

Kedua, mengamati proses/cara berpikir responden yang terpilih saat mengerjakan tes pemecahan masalah yang disesuaikan dengan indikator proses berpikir kreatif menurut tahapan Wallas sekaligus wawancara.

Ketiga, menganalisis proses atau tahapan berpikir kreatif menurut Wallas berdasarkan hasil/jawaban tes pemecahan masalah dan wawancara yang dilakukan oleh responden.

\section{HASIL DAN PEMBAHASAN}

\section{A. Hasil Penelitian}

Berdasarkan perhitungan skor angket ARP (Adversity Response Profile) yang berisi 30 peristiwa dalam kehidupan sehari-hari peneliti menemukan 3 kategori yaitu peralihan quitter menuju camper (QT-CP) sebanyak 1 orang, camper (CP) berjumlah 22 orang dan peralihan camper menuju climber (CP-CB) sebanyak 3 orang, yang dikelompokkan seperti pada Tabel 2. 


\begin{tabular}{|c|c|c|}
\hline \multirow{2}{*}{$\begin{array}{c}\text { Kategori } \\
\text { AQ }\end{array}$} & \multicolumn{2}{|c|}{ Jumlah Siswa } \\
\cline { 2 - 3 } & Laki-Laki & Perempuan \\
\hline QT-CP & 1 orang & 0 \\
\hline CP & 9 orang & 13 orang \\
\hline CP-CB & 0 & 3 orang \\
\hline
\end{tabular}

Selanjutnya dari 3 kategori diatas, responden diambil secara purposive sampling dan berdasarkan pertimbangan dari dosen pembimbing untuk memenuhi 6 responden yang dipilih, maka yang ditentukan sebagai responden yaitu pada Tabel 3.

TABEL 3 PENGELOMPOKKAN RESPONDEN BERDASARKAN KATEGORI AQ

\begin{tabular}{|c|c|c|c|}
\hline No. & Skor & Kategori & KategoriAQ \\
\hline 1. & 92 & $\begin{array}{c}\text { Peralihan Quitter } \\
\text { menuju Camper }\end{array}$ & SQT-1 \\
\hline 2. & 131 & Camper & SCP-1 \\
\hline 3. & 128 & Camper & SCP-2 \\
\hline 4. & 122 & Camper & SCP-3 \\
\hline 5. & 155 & $\begin{array}{c}\text { Peralihan Camper } \\
\text { menuju Climber }\end{array}$ & SCB-1 \\
\hline 6. & 147 & $\begin{array}{c}\text { Peralihan Camper } \\
\text { menuju Climber }\end{array}$ & SCB-2 \\
\hline
\end{tabular}

Selanjutnya keenam responden diberikan tes pemecahan masalah dan peneliti melakukan pengamatan mengenai gerak-gerik siswa selama mengerjakan soal yang diberikan yang disesuaikan dengan tahap proses berpikir kreatif menurut Wallas dan melakukan wawancara mendalam terhadap keenam responden tersebut.

\section{B. Pembahasan}

1. Kategori AQ Rendah (Quitter)

Pada tahap persiapan SQT-1 membuka buku dan bertanya pada subjek lain. Berdasarkan pengamatan oleh peneliti terlihat bahwa SQT-1 kesulitan untuk memecahkan kedua masalah yang diberikan. Pada tahap inkubasi SQT-1 hanya diam dan menggaruk-garuk kepala walaupun berdasarkan wawancara SQT-1 mengatakan sering menjumpai permasalahan seperti yang diberikan oleh peneliti. Pada tahap iluminasi SQT-1 mulai menuliskan yang diketahui dan ditanyakan pada lembar jawaban dan menuliskan rumus. Pada tahap verifikasi, subjek mulai mensubtitusikan data yang diketahui ke dalam rumus.

SQT-1 menyelesaikan kedua soal dengan menggunakan 1 cara penyelesaian namun cara penyelesaiannya kurang sistematis. Selain itu, SQT-1 menuliskan komponen yang diketahui dan ditanyakan, namun di hasil akhir tidak menuliskan satuan dari persamaan yang dituliskannya.

Berdasarkan hasil tes yang diperoleh SQT-1, selain adanya kekeliruan dalam penyelesaian tes, SQT-1 juga menunjukkan perilaku mudah menyerah dan tidak berniat untuk mencari cara lain untuk penyelesaian tes. Hal ini diperoleh berdasarkan kutipan wawancara berikut.
P : Pada saat tadi sementara mengerjakan, ada niat untuk berhenti atau menyerah?

$\mathrm{R}$ : Ada (senyum).

P : SQT-1 tidak ingin menggunakan cara lain untuk penyelesaian?

$\mathrm{R}$ : Tidak (menggelengkan kepala).

$\mathrm{P}$ : Apakah SQT-1 ingin mengulangi dan mengecek kembali perhitungannya?

R : (Menggelengkan kepala).

\section{Kategori AQ Sedang (Camper)}

2.1. Responden SCP-1

Pada tahap persiapan membuka buku dan mengingat-ingat pelajaran yang telah diajarkan. Pada tahap inkubasi, SCP-1 diam sejenak dan berdasarkan wawancara SCP-1 mencari materi dan persamaan yang digunakan. SCP-1 pun mengatakan sering menjumpai permasalahan seperti yang diberikan. Pada tahap iluminasi SCP-1 mulai menuliskan yang diketahui dan ditanyakan dan menuliskan rumus untuk masing-masing soal. Pada tahap verifikasi SCP-1 mulai mensubtitusikan data yang diketahui ke dalam rumus dan menjawab dengan benar.

Berdasarkan wawancara, SCP-1 juga menunjukkan keyakinan akan jawabannya dan tidak ingin mengulangi atau mengecek kembali perhitungannya. Karena, SCP-1 mengatakan bahwa telah berhati-hati dalam mengerjakannya tes yang diberikan. Berikut kutipan wawancara yang diperoleh dari SCP-1.

P : Pada saat sementara menyelesaikan tadi apakah SCP-1 ada niat berhenti mengerjakannya? Maksudnya menyerah saat mengerjakan soal?

R : Tidak sih.

$\mathrm{P}$ : SCP-1 yakin dengan langkah pengerjaan soal yang SCP-1 gunakan ini?

R : Yah, yakin karena sudah cukup jelas persamaannya.

$\mathrm{P}$ : Ingin mengulangi dan mengecek kembali perhitungannya?

R : Tidak, saya sudah berhati-hati dalam mengerjakannya. Jadi tidak perlu pengecekan lagi.

\subsection{Responden SCP-2}

Di tahap persiapan SCP-2 membuka buku untuk menemukan materi yang berhubungan dengan soal yang diberikan. pada tahap inkubasi, SCP-2 diam sejenak dengan menopang dagu dengan kedua tangannya. Pada tahap iluminasi SCP-2 tidak menuliskan komponen yang diketahui dan ditanyakan pada kedua soal yang diberikan, namun langsung 
melakukan operasi perhitungan. Pada tahap verifikasi SCP-2 langsung mensubtitusikan data yang diketahui pada soal kedalam rumus namun jawaban yang diperoleh kurang tepat.

Dari kutipan jawaban SCP-2 menggunakan 2 cara penyelesaian namun hasil yang diperoleh berbeda. Pada cara 1 nilai yang diperoleh sesuai dengan kunci jawaban, namun pada cara 2 nilai yang diperoleh berbeda dengan kunci jawaban. Hal ini terjadi kekeliruan pada proses pencarian nilai kecepatan $v=\sqrt{2 g h}$ nya. Dimana SCP-2 tidak mensubtitusikan hasil selisih tinggi tangki $h_{1}$ dengan tinggi lubang kebocoran dari lantai $h_{2}$, melainkan hanya mensubtitusikan nilai $h_{2}$ pada persamaan yang dituliskan. Selain itu, SCP-2 tidak menemukan jawaban benar, hal ini dikarenakan karena SCP2 tidak mengkonversikan nilai yang masih dalam bentuk CGS ke MKS dan langsung mensubtitusikannya ke dalam rumus yang digunakan sehingga membuat dirinya kesulitan dalam proses penyelesaian soal.

Berdasarkan wawancara, bahwa SCP-2 memahami soal yang diberikan dan tidak merasa kesulitan dalam proses perhitungan. Hal ini terlihat dari kemampuan menjelaskan dengan bahasa sendiri permasalahan apa yang ada pada soal dan mengemukakan apa yang diketahui dan ditanyakan pada soal, walaupun tidak menuliskannya pada lembar jawaban. Walaupun SCP-2 menunjukkan sikap tak yakin dengan jawaban yang diperoleh, namun SCP-2 masih menunjukkan keinginan menemukan cara lain untuk penyelesaian soal dan masih berkeinginan untuk mengecek kembali jawabannya. Berikut kutipan wawancara peneliti dengan SCP-2.

$\mathrm{P}: \quad S C P-2$ kesulitan tidak saat mengerjakan soal nomor 1 dan nomor 2?

R : Ehm, kalau perhitungan sih tidak, cuma kenapa jawabannya tidak betul (tersenyum).

P: Coba jelaskan pakai bahasa sendiri. Nomor 1 maksudnya bagaimana? Nomor 2 maksudnya bagaimana?

R : Ehmm.. Nomor 1 itu dari satu buah tangki ada dikasih lubang dengan ketinggian tertentu dari bawah, diukur dari bawahnya. Kita disuruh ukur dari lubang itu keluar berapa jauh airnya.

$\mathrm{P}$ : Yakin dengan langkah pengerjaan soal yang SCP-2 gunakan?

$\mathrm{R}$ : Tidak.

$\mathrm{P}$ : Tidak ingin menggunakan cara lain?

R : Kalau aku tahu ada cara lain, aku bikin cara lain.

\section{$\mathrm{P}$ : Ingin mengulangi dan mengecek kembali perhitungan? \\ R : Ehm, okay...}

\subsection{Responden SCP-3}

Untuk SCP-3, pada tahap persiapan membuka buku untuk menemukan materi yang berhubungan dengan soal yang diberikan dan SCP-3 mengakui awalnya sedikit merasa kesulitan dan membutuhkan bantuan. Pada tahap inkubasi, SCP-3 membolak-balik buku berkali-kali untuk mencari rumus yang dapat digunakan pada soal yang diberikan. Pada tahap iluminasi SCP-3 menemukan masingmasing 2 cara untuk penyelesaian kedua soal yang diberikan.

Berdasarkan wawancara, SCP-3 mengungkapkan sering menjumpai soal yang diberikan ini pada saat pembelajaran di kelas. SCP-3 juga menunjukkan sikap yang percaya diri dimana SCP-3 menunjukkan keyakinan kebenaran jawaban yang diperoleh dan tidak ingin mengulangi atau mengecek kembali perhitungannya. Selain itu, SCP-3 juga merasa cukup dengan 2 cara penyelesaian yang digunakannya. Berikut kutipan wawancara peneliti dengan SCP-3.

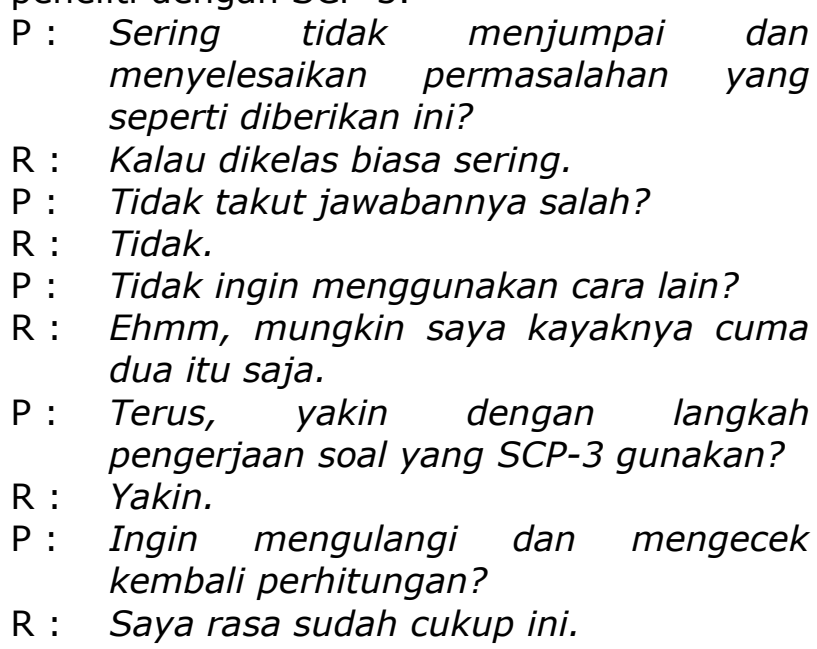

3. Kategori AQ Tinggi (Climber)

3.1. Responden SCB-1

Responden SCB-1, pada tahap persiapan SCB-1 mampu memahami soal dengan baik walaupun ada sedikit kesulitan pada proses perhitungan. Pada tahap inkubasi, SCB-1 membuka buku dan berdasarkan wawancara SCB-1 mengaitkan soal dengan materi yang pernah diajarkan untuk menemukan cara pemecahan masalah. Tahap iluminasi, SCB-1 menemukan 2 cara penyelesaian untuk tiap masing-masing soal dan memperoleh jawaban benar. Tahap verifikasi, SCB-1 mensubtitusikan data yang diperoleh ke dalam rumus dan melakukan operasi perhitungan, namun cara 
penyelesaiannya kurang sistematis. Pada cara pertama untuk persamaan $v=\sqrt{2 g\left(h_{1}-h_{2}\right)}$, $t=\sqrt{\frac{2 h_{2}}{g}}$ dan $x=v \cdot t, \mathrm{SCB}-1$ tidak menuliskan simbol $v, t$ dan $x$ pada rumus dan saat mensubtitusikan data. Sedangkan untuk cara kedua, SCB-1 tidak memaparkan proses memperoleh sudut $\alpha$ yang digunakan pada rumus untuk mendapatkan nilai $x$ nya. Namun, SCB-1 mampu mensubtitusikan semua komponen ke dalam rumus dengan baik, sehingga tidak mengalami kesulitan.

Berdasarkan wawancara diperoleh bahwa SCB-1 menunjukkan ketelitiannya dalam mengerjakan tes, dimana SCB-1 mengemukakan bahwa SCB-1 telah mengecek jawabannya sebelum mengerjakan soal yang lain. SCB-1 juga menunjukkan keyakinan akan benarnya jawaban yang diperoleh dan ingin menemukan cara lain apabila masih diberi kesempatan untuk mengerjakan. Berikut kutipan wawancara peneliti dengan SCB-1.

P : SCB-1 tidak takut pekerjaannya ini salah?

R : Ehm... Sudah. Sudah yakin, karena kan ditengah-tengah pekerjaan kita cek-cek lagi (senyum).

P: Oh terus, tadi pada saat sementara mengerjakan ada niat untuk menyerah mengerjakannya?

R : Tidak. Karena tiada yang namanya meyerah kak. Tidak boleh (senyum). Kan ada kakak peneliti yang bantu untuk penjelasannya bagaimana.

$\mathrm{P}$ : Tidak ingin menggunakan cara lain?

R: Ehm... Kalau ada cara lain, boleh juga cara lain. Cuma baru dua cara itu yang saya ketahui.

P : Kalau misalnya dikasih kesempatan lagi ingin mengulangi perhitungan atau menemukan lagi cara lain untuk mengerjakannya?

$\mathrm{R}$ : Saya ingin menemukan cara yang lain untuk mengerjakannya kak.

\subsection{Responden SCB-2}

Responden SCB-2, Pada tahap persiapan, SCB-2 mampu memahami soal dengan baik walaupun ada sedikit kesulitan dan akhirnya menemukan ide untuk penyelesaian. Pada tahap inkubasi, SCB-2 membuka buku untuk menemukan cara pemecahan masalah tiap masing-masing soal. Tahap iluminasi, SCB-2 menemukan 2 cara penyelesaian untuk tiap masing-masing soal dan memperoleh jawaban benar. Cara pertama, SCB-2 tidak menuliskan rumus dan langsung mensubtitusikan nilai yang diketahui pada rumus. Sedangkan pada cara kedua SCB-2 tidak lengkap menuliskan rumus yang digunakan dalam penyelesaian tes dan tidak menjelaskan proses mendapatkan persamaan penggunaan gerak parabola yang dihubungkan oleh GLBB.

Dari wawancara diperoleh bahwa SCB-2 sedikit diam di tengah penyelesaian soal hal ini dilakukan untuk mengecek kembali jawaban yang diperoleh. Dari wawancara juga diperoleh bahwa SCB-2 menunjukkan keyakinan dari jawaban yang diperoleh dan tidak ingin mengeceknya kembali. Sama halnya dengan SCB-1, SCB-2 juga mengungkapkan bahwa ingin menemukan cara lain untuk penyelesaian kedua soal tersebut. Berikut kutipan wawancara peneliti dengan SCB-2.

\section{P : Tadi kakak lihat sempat diam begitu. Apa yang SCB-2 lakukan? \\ $\mathrm{R}$ : (senyum) mengecek lagi ini apa yang salah dari hasil hitungan itu. \\ P: Merasa kesulitan atau bingung pada saat pengerjaan? \\ $\mathrm{R}$ : Iya lumayan (senyum). \\ $\mathrm{P}$ : Oh, yakin dengan langkah pengerjaan ini yang SCB-2 gunakan? \\ R : Tidak. \\ $\mathrm{P}$ : Tidak ingin menggunakan cara lain untuk pengerjaannya? \\ $\mathrm{R}$ : Sebenarnya mau, cuman belum tahu apa cara yang lain lagi. \\ $\mathrm{P}$ : Ingin mengulangi dan mengecek kembali perhitungannya? \\ R : Sudah tidak.}

\section{A. Kesimpulan}

\section{KESIMPULAN DAN SARAN}

Berdasarkan hasil analisis data dan pembahasan, maka diperoleh kesimpulan sebagai berikut:

1. Siswa AQ rendah (Quitter) hanya memenuhi sedikit indikator berpikir kreatif menurut tahapan Wallas. Siswa quitter ini lebih banyak menunjukkan tahap inkubasinya dibanding ketiga tahap yang lain, sehingga tidak menunjukkan usahanya selama mengerjakan tes.

2. Siswa AQ sedang (Camper) mampu memenuhi beberapa indikator berpikir kreatif menurut tahapan Wallas dan masih menunjukkan usahanya dalam menemukan cara lain penyelesaian walaupun merasa sedikit kesulitan.

3. Siswa AQ tinggi (Climber) hampir memenuhi semua indikator berpikir kreatif menurut tahapan Wallas dan menunjukkan sikap antusiasnya dalam mengerjakan tes serta 
menunjukkan bahwa siswa climber pantang menyerah.

B. Saran

Berdasarkan kesimpulan di atas, maka saran yang dapat diberikan pada penelitian ini adalah:

1. Guru diharapkan mendesain model pembelajaran tidak hanya meningkatkan hasil belajar, tetapi juga mampu mengembangkan kemampuan berpikir kreatif siswa.

2. Guru diharapkan membiasakan siswa terlibat dalam soal yang menuntut siswa untuk berpikir divergen.

3. Peneliti selanjutnya, kiranya dapat melakukan penelitian sejenis dengan materi dan lokasi penelitian yang berbeda guna memperoleh hasil yang lebih baik.

\section{DAFTAR PUSTAKA}

[1] F. Nurrahmah. Profil Proses Berpikir Kreatif Siswa Kelas $X$ Menurut Wallas dalam Memecahkan Masalah Pada Materi Pokok Gerak Lurus Ditinjau dari Jenis Kelamin dan Prestasi Belajar Fisika. Skripsi Program Studi Pendidikan Fisika. Semarang: UIN Walisongo Semarang. 2015.

[2] T.Y.E. Siswono., dan Y. Kurniawati. "Penerapan Model Wallas untuk Mengidentifikasi Proses Berpikir Kreatif
Siswa dalam Pengajuan Masalah Matematika dengan Informasi Berupa Gambar". Junal Nasional Matematika. $1,(1), 1-20.2004$.

[3] W.Y., Isvina., T. Sugiarti., dan D. Kurniati. "Proses Berpikir Kreatif dalam Memecahkan Sub Pokok Bahasan Trapesium Berdasarkan Tahapan Wallas Ditinjau dari Adversity Quotient (AQ) Siswa Kelas VII-C SMP Negeri 1 Jember". Artikel Ilmiah Mahasiswa. 1, (1), 1-7. 2015.

[4] R. Uloli, Probowo, dan T. Prastowo. Kajian Konseptual Proses Berpikir Kreatif dan Pemecahan Masalah: Seminar Nasional Pendidikan dan Saintek. Surabaya: Pasca Sarjana UNESA, Surabaya. 2016.

[5] E. Wulantina, T.A. Kusmayadi, dan Riyadi. "Proses Berpikir Kreatif Siswa dalam Pemecahan Masalah Matematika Ditinjau dari Kemampuan Matematika Pada Siswa Kelas X MIA SMAN 6 Surakarta". Jurnal Elektronik Pembelajaran Matematika. 1, (6), 671-682. 2015.

[6] A.P. Yanti dan M. Syazali. "Analisis Proses Berpikir Siswa dalam Memecahkan Masalah Matematika Berdasarkan Langkah-Langkah Bransford dan Stein Ditinjau dari Adversity Quotient Siswa Kelas X MAN 1 Bandar Lampung Tahun 2015/2016". Jurnal Pendidikan Matematika. 108-122. 2015.

[7] D.A. Setyorini. Profil Pemecahan Masalah Sub Pokok Bahasan Sistem Persamaan Linear Dua Variabel Pada Siswa Kelas IX MtsN 1 Jember dengan Tahapan Polya Ditinjau Berdasarkan Adversity Quotient (AQ). Skripsi Program Studi Pendidikan Matematika. Jember: Universitas Jember. 2016.

[8] I.N.L. Fauziyah, B. Usodo, dan H. Ekana, "Proses Berpikir Kreatif Siswa Kelas X dalam Memecahkan Masalah Geometri Berdasarkan Tahapan Wallas Ditinjau dari Adversity Quotient (AQ) Siswa". Jurnal Pendidikan Matematika. 1-16. 2016. 